\title{
Parapatric Distribution of the Lizards Plestiodon (Formerly Eumeces) latiscutatus and $P$. japonicus (Reptilia: Scincidae) Around the Izu Peninsula, Central Japan, and Its Biogeographic Implications
}

\author{
Taku Okamoto*, Junko Motokawa, Mamoru Toda and Tsutomu Hikida \\ Department of Zoology, Graduate School of Science, Kyoto University, \\ Kitashirakawa-oiwakecho, Sakyo-ku, Kyoto 606-8502, Japan
}

\begin{abstract}
The scincid lizard Plestiodon latiscutatus is found in the Izu Islands and Izu Peninsula of central Japan, whereas $P$. japonicus, a close relative, is found over the entire main island group of Japan, except the Izu Peninsula. The precise area of occupancy of these species was surveyed around the Izu Peninsula. Species identification was made through comparison of mitochondrial DNA partial sequences of specimens from the Izu Peninsula with those from the other regions, since morphological differences between these species have not yet been characterized. This study determined that these species are deeply diverged from each other in mitochondrial DNA sequence, and that the ranges of these species overlap only in a narrow zone. The results imply that gene flow between these species, if any, is restricted to a low level, without physical barriers. The boundary between the geographic ranges of these species was established as occurring along the lower Fuji River, Mt. Fuji, and the Sakawa River. This region is concordant with that of the old sea that is assumed to have separated the Izu Peninsula from other parts of the Japanese main island group until the middle Pleistocene. This pattern suggests that $P$. latiscutatus and $P$. japonicus were differentiated allopatrically before the connection of land areas of the Izu Peninsula and Honshu, the main island of Japan, and come into secondary contact through this connection. Thus, the species boundary is likely to have been maintained in situ, without physical barriers, since the secondary contact in the middle Pleistocene.
\end{abstract}

Key words: Plestiodon latiscutatus, Plestiodon japonicus, parapatry, secondary contact, Izu Peninsula, mitochondrial DNA

\section{INTRODUCTION}

The recent accumulation of phylogeographic studies using genetic markers has revealed occurrences of genetically differentiated entities that are difficult to recognize by morphological approaches alone. An array of studies has demonstrated that these entities have various geographic arrangements, for example in Japan, the allopatry of salamanders (Nishikawa et al., 2001, 2005), the parapatry of land snails (Hayashi and Chiba, 2000, 2004; Shimizu and Ueshima, 2000; Watanabe and Chiba, 2001) and ground beetles (Su et al., 1998), and the sympatry of geckos (Toda et al., 2001a, b) and salamanders (Tominaga et al., 2003). How such genetic differentiation is maintained despite a close relationship is an important question in the study of biodiversity. In cases of allopatry, there is virtually no interaction between isolated populations, and the occurrence and maintenance of genetic differentiation can be explained by the physical barrier. In cases of parapatry and sympatry,

\footnotetext{
${ }^{*}$ Corresponding author. Phone: $+81-75-753-4076$; Fax : +81-75-753-4114; E-mail: tak@zoo.zool.kyoto-u.ac.jp
}

there can be various types of interactions between populations, some of which, such as assortative mating (e.g., McMillan et al., 1997) or selection against hybrids (e.g., MacCallum et al., 1995), should maintain genetic differentiation. Thus, the presence or absence of any interactions between particular populations is the most fundamental consideration in inferring maintenance mechanisms. This can be resolved by determining the precise area of occupancy of the populations.

Until recently, the common scincid lizard that occurs throughout the entire Japanese main island group had been recognized as Eumeces latiscutatus (Hallowell, 1861), whereas the populations on the Izu Islands had been recognized as a closely related species, E. okadae Stejneger, 1907 (Taylor, 1936; Nakamura and Uéno, 1963; Hikida, 1993; Kato et al., 1994; Hikida, 1996). By examining allozyme variation in $E$. latiscutatus throughout the entire Japanese main island group, Motokawa and Hikida (2003) found that the populations on the Izu Peninsula of central Honshu (Fig. 1-B) are distinct from the other populations on the Japanese main island group, and closely related to E. okadae. Based on this result, they concluded that Eumeces on the Izu Peninsula is a distinct species from those of the remaining part of the Japanese main island group, and conspecific 


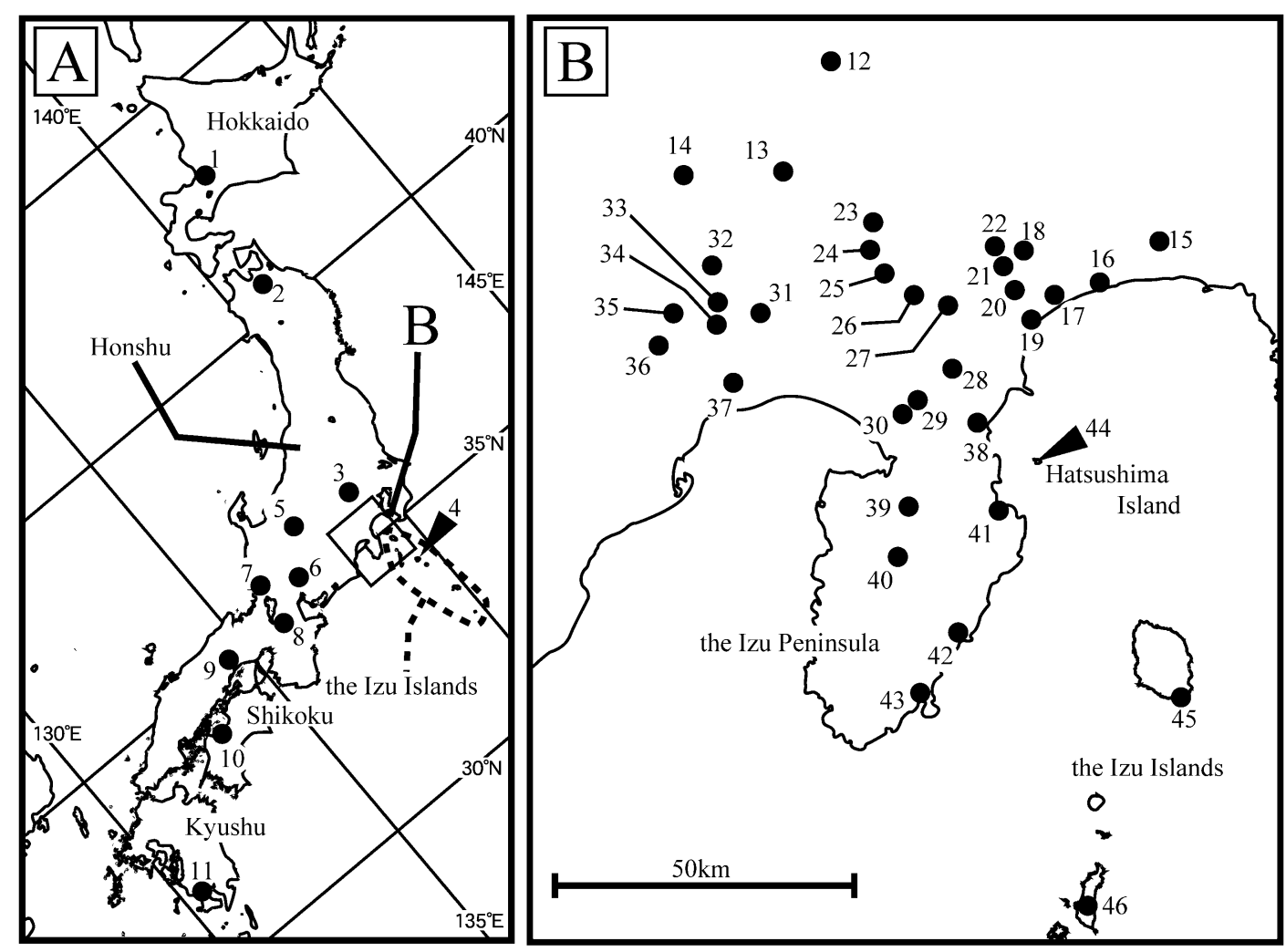

Fig. 1. Localities where the specimens were collected. A) The entire Japanese main island group. B) Izu Peninsula. See Appendix 1 for details.

with E. okadae. Because the type locality of $E$. latiscutatus is the southern Izu Peninsula (Shimoda: 43 in Fig. 1-B), they argued that $E$. okadae should be recognized as a junior synonym of $E$. latiscutatus, and that the previously suppressed name E. japonicus Peters, 1864 (type locality: Nagasaki, near 11 in Fig. 1A) should be resurrected for the other species distributed over the remainder of the Japanese main island group. In addition, recent phylogenetic studies (Griffith et al., 2000; Schmitz et al., 2004; Brandley et al., 2005) and the taxonomic literature (Smith, 2005) have indicated that East Asian members of the genus Eumeces (sensu lato), including E. latiscutatus and E. japonicus, should be recognized as a separate genus, Plestiodon. In the present paper, we follow Motokawa and Hikida (2003), and Brandley et al. (2005) and Smith (2005) for the specific and generic classifications, respectively.

Motokawa and Hikida's (2003) findings indicated that the two closely related species are distributed within central Honshu. This situation prompted us to the question how their genetic differentiation has been maintained. To answer this question, an examination of the exact geographic distributions of Plestiodon latiscutatus and $P$. japonicus is critical. We surveyed the precise geographic distributions of these species on the basis of a number of specimens collected from the Izu Peninsula and adjacent regions. The Izu Peninsula population of $P$. latiscutatus is nearly identical to $P$. japonicus in external morphology (Motokawa and Hikida, 2003), and therefore identification without genetic markers is difficult. Thus, we first analyzed DNA sequence variation within and between these species to determine fixed differ- ences between them, and then identified each specimen collected from the Izu Peninsula and adjacent regions on the basis of these differences.

\section{MATERIALS AND METHODS}

\section{Samples examined}

A total of 180 specimens of Plestiodon latiscutatus and $P$. japonicus were collected from 46 localities on the Japanese main island group and several adjacent islands, including some parts of the Izu Islands (Fig. 1; see Appendix 1 for details). To clarify whether the geographic ranges of these species overlapped, intensive surveys were made in the Izu Peninsula and adjacent regions (Fig. 1B). One specimen of $P$. barbouri, a closely related species (Hikida, 1993; Kato et al., 1994), was used as an outgroup in the genealogical inference. Liver or skeletal muscle tissue was taken from each specimen and stored at $-80^{\circ} \mathrm{C}$ or in $99 \%$ ethanol.

\section{Identification of specimens from the Izu Peninsula}

We identified specimens from the Izu Peninsula as $P$. latiscutatus or $P$. japonicus by comparing mitochondrial DNA (mtDNA) sequences. Prior to identification of these specimens, genetic variation within and between the two species was evaluated by inferring the gene genealogy among haplotypes from various localities. For this analysis, nucleotide sequences were determined for 26 specimens from 21 localities around the Izu Peninsula (12-17, 19, 23, 24, 27-30, 33, 36, 40, 43, 44 in Fig. 1) and Izu Islands (4, 45, 46 in Fig. 1), and 10 specimens from 10 other localities around the Japanese main island group (1-3, 5-11 in Fig. 1).

In the inferred genealogy, two distinct groups were evident: one consisted of haplotypes from the Izu Peninsula and Izu Islands, and the other consisted of those from the Japanese main island group (see Results). Because the geographic ranges of the two groups 
agreed well with those of the two species delineated by a previous allozyme study (Motokawa and Hikida, 2003), these haplotypes were regarded as representative of $P$. latiscutatus and $P$. japonicus, respectively. By comparing nucleotide sequences between the two haplotype groups, fixed nucleotide differences between these species were detected. Using restriction enzymes recognizing some of the fixed differences, the remaining 144 specimens were identified without sequencing by polymerase chain reaction - restriction fragment length polymorphism (PCR-RFLP) analysis (see below for further details).

\section{Nucleotide sequencing and PCR-RFLP genotyping}

Total DNA was extracted using the methods of Wada et al. (1992) and Honda et al. (1999). Tissues were frozen with liquid nitrogen, crushed, and lysed in lysis buffer $(10 \mathrm{mM}$ Tris- $\mathrm{HCl}[\mathrm{pH}$ 8.0], $10 \mathrm{mM}$ EDTA [pH 8.0], $150 \mathrm{mM} \mathrm{NaCl}, 0.1 \%$ SDS). After digestion of samples with proteinase $\mathrm{K}(100 \mu \mathrm{g} / \mathrm{ml})$ at $50-55^{\circ} \mathrm{C}$ for three hours, DNA was extracted two or three times with phenol and once with 25:24:1 phenol/chloroform/isoamyl-alcohol, and precipitated in two volumes of $99 \%$ ethanol with one-tenth volume of $5.0 \mathrm{M}$ sodium acetate ( $\mathrm{pH}$ 5.2). Precipitated samples were dried and stored in TE buffer (10 mM Tris-HCl [pH 8.0], $1 \mathrm{mM}$ EDTA [pH 8.0]). Part of the mitochondrial $12 S$ and $16 S$ rDNA regions were amplified with a PCR System GeneAmp 2400 or 2700 Thermal Cycler (Applied Biosystems, Lincoln, USA), using an Ex Taq Polymerase Kit (Takara Shuzo Co., Ltd., Otsu, Japan) and the primers L1091 (5'-AAACTGGGATTAGATACCCCACTAT-3') and H1478 (5'-GAGGGTGACGGGCGGTGTGT-3') for 12S rDNA (Kocher et al., 1989), and L2606 (5'-CTGACCGTGCAAAGGTAGCGTAATCACT-3') and H3056 (5'CTCCGGTCTGAACTCAGATCACGTAGG-3') for 16S rDNA (Hedges et al., 1993; Honda et al., 1999). Both the 12S and 16S regions were sequenced directly; however, only $16 \mathrm{~S}$ was used for RFLP analysis. The thermocycling regime was 30 cycles of $1 \mathrm{~min}$ at $94^{\circ} \mathrm{C}$, 2 min at $55^{\circ} \mathrm{C}$, and $3 \mathrm{~min}$ at $72^{\circ} \mathrm{C}$, with an initial denaturation step of $5 \mathrm{~min}$ at $94^{\circ} \mathrm{C}$ and a final extension of $7 \mathrm{~min}$ at $72^{\circ} \mathrm{C}$.

PCR products were purified by polyethylene glycol (PEG) precipitation using 0.6 volume of PEG solution (20\% PEG $6000,2.5 \mathrm{M}$ $\mathrm{NaCl}$ ) and then sequenced with a Big Dye Terminator Cycle Sequencing Ready Reaction Kit v1.0 and ABI PRISM 377 DNA Sequencer or ABI PRISM 310 Genetic Analyzer (Applied Biosystems, Lincoln, USA), using the primers described above. The sequence data have been submitted to the GenBank database (Accession Nos. DQ173497-DQ173534).

For RFLP, aliquots of $16 \mathrm{~S}$ rDNA PCR products were digested for three or four hours with two enzymes separately, Dra I and BsiHKA I (Promega Corp., Madison, USA). These enzymes were selected to discriminate latiscutatus from japonicus sequences; the former cuts latiscutatus sequences only, whereas the latter cuts japonicus sequences only. The digested samples were subjected to $2 \%$ agarose gel electrophoresis in TAE buffer, stained by ethidium bromide $(0.5 \mathrm{~g} / \mathrm{mL})$, and viewed with UV illumination.

\section{Inference of gene genealogy of mtDNA}

In the inference of genealogy, identical sequences were treated as a single unit. Sequences were automatically aligned in ClustalX version 1.81 (Thompson et al., 1997), and then adjusted by eye considering inferred secondary structures (not shown) of the $12 \mathrm{~S}$ and 16S rRNA of Plestiodon egregius (GenBank Accession No. AB016606; Kumazawa and Nishida, 1999). The rRNA secondary structures of $P$. egregius were inferred by comparison with the hypothetical secondary structure of the homologous rRNAs of some other vertebrates available at the CRW site (Cannone et al., 2002). The mtDNA genealogy was inferred under the maximum likelihood (ML) criterion (Felsenstein, 1981), following a chi-square test to determine whether there was homogeneous equilibrium of base composition among sequences. Gaps inserted through alignment were treated as missing data. The optimal model (GTR with a gamma-distributed heterogeneous substitution rate among sites) of sequence evolution assumed in the ML inference was selected among the available models in TREEFINDER version March 2004 (Jobb, 2004) based on the Akaike information criterion (AIC: Akaike, 1974; Posada and Crandall, 1998). Support for the inferred topology was assessed by bootstrap probabilities (Felsenstein, 1985) with 1000 pseudoreplicates. The chi-square test for base composition bias, search for the ML tree, and bootstrapping were conducted with TREEFINDER version March 2004 (Jobb, 2004).

Table 1. Haplotype - locality correspondence. The designations of haplotypes $(\mathrm{a}-\mathrm{r})$ and the numbers for localities correspond to those in Fig. 2 and Fig. 1, respectively.

\begin{tabular}{|c|c|c|}
\hline & haplotype & locality \\
\hline \multirow{5}{*}{ P. latiscutatus } & a & 4 \\
\hline & $\mathrm{b}$ & 46 \\
\hline & c & 29 \\
\hline & $d$ & 19, 24 (two individuals), 27, 28, 33, 40, 43, 44, 45 \\
\hline & $\mathrm{e}$ & 30 \\
\hline \multirow{13}{*}{ P. japonicus } & $f$ & 11 \\
\hline & $g$ & 10 \\
\hline & $\mathrm{h}$ & 8 \\
\hline & $\mathrm{i}$ & 9 \\
\hline & j & 6 \\
\hline & $\mathrm{k}$ & 7 \\
\hline & I & 23 \\
\hline & $\mathrm{m}$ & 23 \\
\hline & $\mathrm{n}$ & 2 \\
\hline & o & 12,13 \\
\hline & $\mathrm{p}$ & $1,5,14,15,16,24,36$ \\
\hline & $q$ & 17 \\
\hline & $\mathrm{r}$ & 3,24 (two individuals) \\
\hline
\end{tabular}

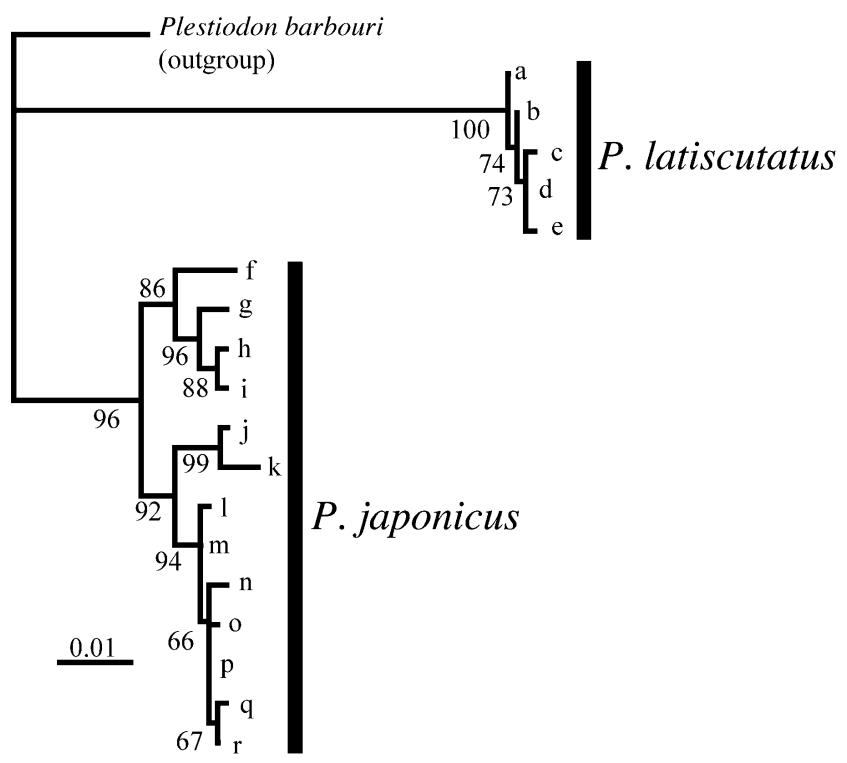

Fig. 2. Maximum likelihood tree showing genealogical relationships among 18 observed haplotypes of $12 S+16 S$ rDNA partial sequences (approximately $815 \mathrm{bp}$ ) from 36 specimens. Each unit (a-r) denotes one the 18 observed haplotypes. The localities of the specimens with each haplotype are presented in Table 1. The numbers at the internal edges indicate bootstrap probabilities (\%). Only those greater than $50 \%$ are shown. 


\section{RESULTS}

\section{Genetic differentiation between species}

In the 36 ingroup specimens sequenced, 18 haplotypes were observed (Table 1). No significant deviation from an assumption of homogeneous base composition equilibrium was found. The multiple alignment of the 18 sequences and the outgroup contained few gaps, none of which was longer than one base pair. The combined aligned sequences were 815 bp long (12S rRNA, 385bp; 16S rRNA, 430bp), with 92 and 80 variable sites for $12 S$ and $16 S$, respectively.

The maximum likelihood tree (Fig. 2) showed two distinct

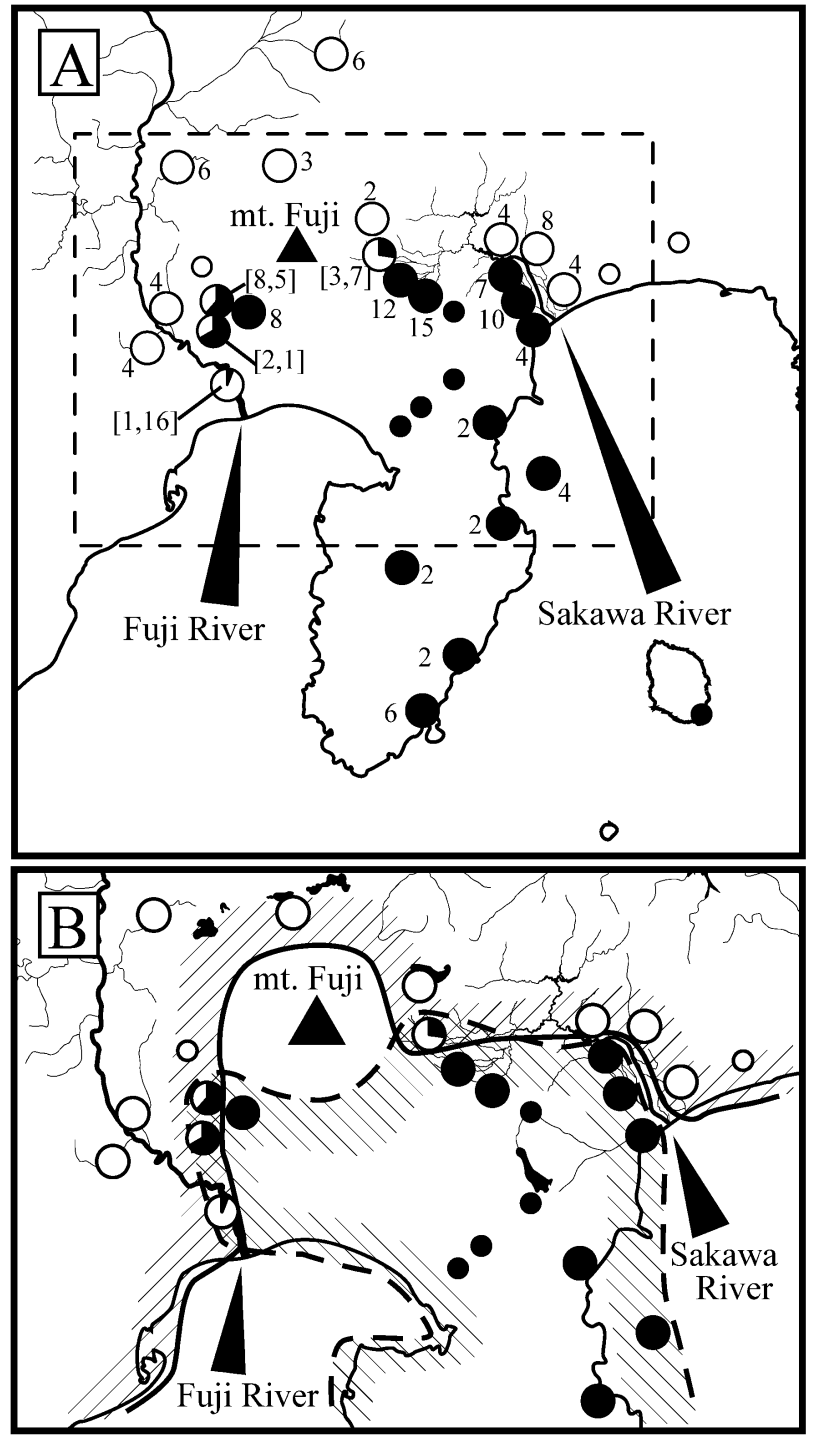

Fig. 3. A) Species composition of local samples. The small and large pie graphs indicate localities with one specimen and with two or more specimens, respectively. The solid and open sectors of each pie graph denote the fractions of $P$. latiscutatus and $P$. japonicus, respectively. The numbers adjacent to each pie graph are sample sizes. The numbers in brackets (left and right) indicate the number of $P$. latiscutatus and $P$. japonicus, respectively, at localities having both species. B) The ranges of $P$. latiscutatus (surrounded by a dashed line) and $P$. japonicus (surrounded by a solid line) around the Izu Peninsula, estimated from the data in A. groups. A deep divergence $(6.43 \%$ mean pairwise $p$-distance) was observed between the two groups, compared to divergences within the groups $(0.08 \%$ in the upper group in Fig. 2, $0.93 \%$ in the lower). The upper group included the specimens from the Izu Islands and Izu Peninsula and can be regarded as having haplotypes representing Plestiodon latiscutatus. The lower group included the specimens from the entire Japanese main island group except the Izu Peninsula, and can be regarded as having haplotypes of $P$. japonicus.

A comparison of 16S rDNA consensus sequences (not shown) between $P$. latiscutatus and $P$. japonicus showed fixed differences at 18 sites. In the subsequent PCR-RFLP analysis that incorporated a subset of these fixed differences, all 144 specimens were identified unambiguously as $P$. latiscutatus or $P$. japonicus.

\section{Geographic ranges of Plestiodon latiscutatus and $P$. japonicus}

The species composition of each local sample around the Izu Peninsula is presented in Fig. 3A. Specimens identified as $P$. latiscutatus were found on and near the Izu Peninsula (19-21, 24-31, 33, 34, 37-43 in Fig. 1), Hatsushima Island (44 in Fig. 1), and the Izu Islands (4, 45, 46 in Fig. 1). In contrast, specimens identified as $P$. japonicus were found from the whole Japanese main island group except the Izu Peninsula (1-3, 5-18, 22-24, 32, 33, 34-37 in Fig. 1). The boundary between these two species was located along the lower Fuji River, the eastern and western sides of Mt. Fuji, and along the Sakawa River (Fig. 3-B). Along the boundary were four localities with both species $(24,33,34,37$ in Fig. 1). Thus, these species are parapatrically distributed, with a narrow overlap zone (Fig. 3B).

At the localites along the boundary $(24,33,34,37$ in Fig. 1), several specimens of both species were collected together at the same time and in the same microhabitat. For example, at locality 24 (Fig. 1), two individuals of $P$. latiscutatus (collection nos. KUZ R58316, 58319) and two individuals of $P$. japonicus (KUZ R58317, 58318) were collected from the same crack in a stone wall at the same time.

\section{DISCUSSION}

\section{Current interspecific interactions}

With respect to current interspecific interactions, three important aspects of our results should be addressed: (1) a deep divergence in mtDNA haplotypes exists between Plestiodon latiscutatus and $P$. japonicus (Fig. 2); (2) overlap of the geographic distribution of these species is limited to quite a narrow zone (Fig. 3); and (3) the two species were collected together at several localities along the narrow overlap zone.

The first and second aspects imply that gene flow between these species has been restricted to a low level for a considerable period. If there were a high or moderate level of gene flow between the two species, both species would either have become fixed to one of the two lineages, or the observed geographic ranges of the two mtDNA types would have overlapped greatly, by high spatial mobility and fast lineage sorting of mtDNA (Ferris et al., 1983; Takahata and Slatkin, 1984; Avise, 2000). Instead, our results suggest that interspecific gene flow, if any, is at a low level. Concordance 
between the geographic distribution of allozyme variants (Motokawa and Hikida, 2003) and mtDNA haplotypes additionally supports this conclusion. The third aspect, co-occurrences of individuals of these species, suggests that there is no physical barrier against interspecific interaction.

Together, these three aspects suggest that genetic differentiation between $P$. latiscutatus and $P$. japonicus is maintained by intrinsic reproductive isolation mechanisms, rather than a physical barrier. Although the boundary of the two species partly consists of the Sakawa River and the lower part of the Fuji River, the homogeneity of the mtDNA sequences within each species (Fig. 2), despite many other rivers in the region (such as upper part of the Fuji River: Fig. $3-A)$, suggests that a river itself is not a strict barrier to gene flow. Thus, we postulate that the genetic differentiation is maintained without any physical barriers. Nontheless, because our analyses are based on mtDNA data only, local hybridization along the boundary could have been overlooked. Further studies using nuclear genetic markers are needed to clarify this issue.

\section{Origin of the parapatric distribution}

A parapatric distribution of a pair of closely related species can arise in two ways: by primary intergradation through parapatric speciation, or by secondary contact preceded by allopatric differentiation (e.g., Barton and Hewitt, 1985). Based on a theoretical study, Endler (1977) argued that without paleontological data it is difficult to distinguish between these two processes by interpreting a present geographic pattern. Nevertheless, independent geological evidence of a physical barrier in the past sometimes supports an origin by secondary contact of the parapatry of genetically differentiated entities. The parapatry of Plestiodon around the Izu Peninsula is such a case.

The Izu Peninsula is the current northern tip of the Philippine Sea Plate (Sugimura, 1972) and is assumed to have been separated from the remaining part of Honshu by the sea until the middle Pleistocene (Kitazato, 1997). Land areas of the Izu Peninsula and Honshu were connected in the middle Pleistocene (0.7 MYA) through the northward movement of the Philippine Sea Plate (e.g., Kitazato, 1997; Takahashi and Saito, 1997). Stratigraphic evidence (Kimura, 1985; Kitazato, 1997; Imanaga, 1999) indicates that the old sea covered only the region of the present-day Sakawa River and the lower part of the Fuji River (Fig. 4). Stratigraphic data for the same period is not available for the region around Mt. Fuji, because this region is covered with newer, thick volcanic material. In any case, the location of the old sea that had separated the Izu Peninsula from Honshu is concordant with the distributional boundary between $P$. latiscutatus and $P$. japonicus.

This concordance supports a hypothesis of parapatry by secondary contact between $P$. latiscutatus and $P$. japonicus. It appears that the distribution of these species around the Izu Peninsula is older than the land connection between the Izu Peninsula and Honshu; that is, before the land connection, the old islands of the Izu Peninsula and Izu Islands were already occupied by the ancestor of $P$. latiscutatus, whereas the side of the Japanese main island group was already occupied by the ancestor of $P$. japonicus. Thereafter, these species came into secondary contact through the

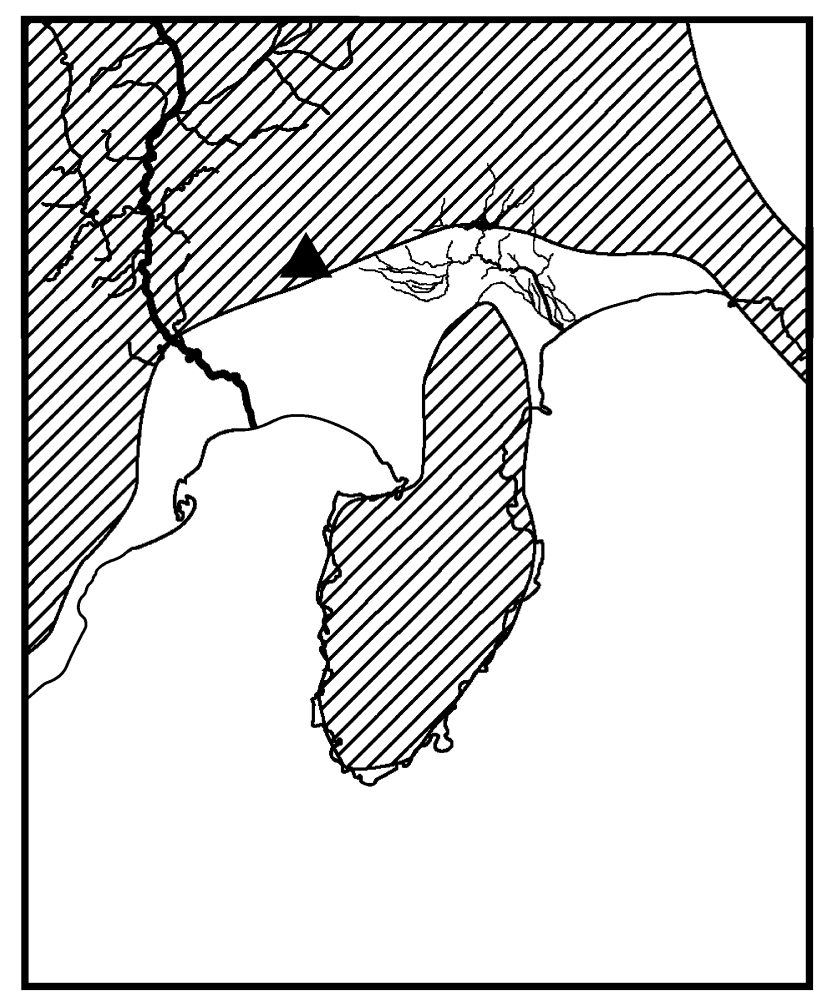

Fig. 4. Paleogeographic map of the Izu Peninsula in the early Pleistocene (modified from Kimura, 1985). Shaded parts indicate land areas.

connection of these land areas, which is assumed to have occurred at 0.7 MYA (Kitazato, 1997). If this was the case, the species boundary has been maintained without physical barriers in situ for a long time.

Differentiation between populations of the Izu Peninsula and other parts of Honshu, and/or an affinity between the Izu Peninsula and the Izu Islands, has also been reported for several other organisms at the levels of faunas and populations. For example, there have been studies on the landsnail fauna (Habe, 1977) and the phylogeographic patterns of sea slaters (Itani, 1999, 2000) and land snails (Hayashi and Chiba, 2000, 2004; Shimizu and Ueshima, 2000; Watanabe and Chiba, 2001). The similarities in geographic differentiation patterns among these unrelated organisms implies isolation by a common extrinsic factor. This also supports our historical scenario of parapatry by secondary contact for $P$. latiscutatus and $P$. japonicus. Further study is required at both the faunal and population levels to better understand the origin of the fauna of the Izu Peninsula and the Izu Islands.

\section{ACKNOWLEDGMENTS}

Part of this study was conducted at the Laboratory of Phylogeny, Department of Biology, Faculty of Science, Chiba University in 2000. We are grateful to S. Kurita, M. Ito, T. Asakawa, S. Aoki and the other staff of the laboratory at the time for their careful teaching of basic techniques. We also express our gratitude to N. Sato for accommodating us with the DNA auto sequencer, to K. Armstrong for valuable comments on the manuscript, and to $S$. Ikeda, $Y$. Kokuryo, Y. Misawa, and T. Shimada for providing some of the materials. This study was partially supported by a Grant-in-Aid from 
the Ministry of Education, Science, Sports and Culture of Japan for Scientific Research to TH (no. C-10836010) and to the Biodiversity Research of the 21 st Century COE (A14).

\section{REFERENCES}

Akaike $H$ (1974) A new look at the statistical model identification. IEEE Trans Autom Contr 19: 716-723

Avise JC (2000) Phylogeography: The History and Formation of Species. Harverd University Press, Cambridge, Massachusetts

Barton NH, Hewitt GM (1985) Analysis of hybrid zones. Annu Rev Ecol Syst 16: 113-148

Brandley MC, Schmitz A, Reeder TW (2005) Partitioned Bayesian analyses, partition choice, and the phylogenetic relationships of scincid lizards. Syst Biol 54: 373-390

Cannone JJ, Subramanian S, Schnare MN, Collett JR, D'Souza LM, Du Y, Feng B, Lin N, Madabusi LV, Müller KM, Pande N, Shang Z, Yu N, Gutell RR (2002) The Comparative RNA Web (CRW) site: an online database of comparative sequence and structure information for ribosomal, intron, and other RNAs. BMC Bioinformatics 3: 2

Endler JA (1977) Geographic Variation, Speciation, and Clines. Monographs in Population Biology. Princeton University Press, Princeton

Felsenstein J (1981) Evolutionary trees from DNA sequences: a maximum likelihood approach. J Mol Evol 17: 368-376

Felsenstein J (1985) Confidence limits on phylogenies: an approach using the bootstrap. Evolution 39: 783-791

Ferris SD, Sage RD, Huang CM, Nielsen JT, Ritte U, Wilson AC (1983) Flow of mitochondrial DNA across a species boundary. Proc Natl Acad Sci USA 80: 2290-2294

Griffith H, Ngo A, Murphy RW (2000) A cladistic evaluation of the cosmopolitan genus Eumeces Wiegmann (Reptilia, Squamata, Scincidae). Russ J Herpetol 7: 1-16

Habe T (1977) Land molluscan fauna of the Izu Islands and its biogeographical significance. Mem Natl Sci Mus 10: 77-82 (in Japanese with English abstract)

Hallowell E (1861) [1860] Report upon the Reptilia of the North Pacific exploring expedition, under command of Capt. John Roger. Proc Acad Nat Sci Phil 1860: 480-510

Hayashi M, Chiba S (2000) Intraspecific diversity of mitochondrial DNA in the land snail Euhadra peliomphala (Bradybaenidae). Biol J Linn Soc 70: 391-401

Hayashi M, Chiba S (2004) Enhanced colour polymorphisms in island populations of the land snail Euhadra peliomphala. Biol J Linn Soc 81: 417-425

Hedges SB, Nussbaum RA, Maxson LR (1993) Caecilian phylogeny and biogeography inferred from mitochondrial DNA sequences of the 12S rRNA and 16S rRNA genes (Amphibia: Gymnophiona). Herpetol Monogr 7: 64-76

Hikida T (1993) Phylogenetic relationships of the skinks of the genus Eumeces (Scincidae: Reptilia) from East Asia. Jpn J Herpetol 15: 1-21

Hikida T (1996) Scincidae. In "The Encyclopedia of Animals in Japan 5, Amphibians, Reptiles, Chondrichthyes" Ed by S Sengoku, T Hikida, M Matsui, K Nakaya, Heibonsha, Tokyo, pp 8082 (in Japanese)

Honda M, Ota H, Kobayashi M, Nabhitabhata J, Yong HS, Hikida T (1999) Phylogenetic relationships of the flying lizards genus Draco (Reptilia, Agamidae). Zool Sci 16: 535-549

Imanaga I (1999) Stratigraphy and tectonics of the Ashigara group in Izu collision zone, central Japan. Bull Kanagawa Pref Mus Nat Sci 28: 73-106

Itani Y (1999) Molecular phylogeography of the genus Ligia in Japanese islands. Konchu to Shizen 34 (2): 39-41 (in Japanese)

Itani Y (2000) Phylogeography of Japanese Ligia species (Isopoda: Crustacea) based on molecular phylogenetic analysis. Ph. D. thesis, Graduate School of Science, Kyoto University
Jobb G (2004) TREEFINDER version March 2004. Munich, Germany. Distributed by the author at www.treefinder.de

Kato J, Ota H, Hikida T (1994) Biochemical systematics of the latiscutatus species-group of the genus Eumeces (Scincidae: Reptilia) from East Asian islands. Biochem Syst Ecol 22: 491-500

Kimura T (1985) The Japanese Islands - The History of Formation Vol III, Kokon Shoin, Tokyo (in Japanese)

Kitazato H (1997) Paleogeographic changes in central Honshu, Japan, during the late Cenozoic in relation to the collision of the Izu-Ogasawara Arc with the Honshu Arc. Isl Arc 6: 144-157

Kocher TD, Thomas WK, Meyer A, Edwards SV, Pääbo S, Villablanca FX, Wilson AC (1989) Dynamics of mitochondrial DNA evolution in animals: amplifications and sequencing with conserved primers. Proc Natl Acad Sci USA 86: 6196-6200

Kumazawa Y, Nishida M (1999) Complete mitochondrial DNA sequences of the green turtle and blue-tailed mole skink: statistical evidence for archosaurian affinity of turtles. Mol Biol Evol 16: 784-792

MacCallum CJ, Nürberger B, Barton NH (1995) Experimental evidence for habitat dependent selection in Bombina hybrid zone. Proc R Soc Lond Ser B Biol Sci 260: 257-264

McMillan WO, Jiggins CD, Mallent J (1997) What initiates speciation in passion-vine butterflies? Proc Natl Acad Sci USA 94: 86288633

Motokawa J, Hikida T (2003) Genetic variation and differentiation in the Japanese five-lined skink, Eumeces latiscutatus (Reptile: Squamata). Zool Sci 20: 97-106

Nakamura K, Uéno SI (1963) Japanese Reptiles and Amphibians in Color. Hoikusha, Osaka, Japan (in Japanese)

Nishikawa K, Matsui M, Tanabe S (2005) Biochemical phylogenetics and historical biogeography of Hynobius boulengeri and $H$. stejnegeri (Amphibia: Caudata) from the Kyushu region, Japan. Herpetologica 61: 54-62

Nishikawa K, Matsui M, Tanabe S, Sato S (2001) Geographic enzyme variation in a Japanese salamander, Hynobius boulengeri Thompson (Amphibia: Caudata). Herpetologica 57: 281-294

Peters WCH (1864) Über die Eidechsenfamilie der Scincoiden, insbesondere über die Schneider'schen, Wiegmann'schen, und neue Arten des zoologischen Museums. Mber Königl Akad Wiss Berlin 1864 (Januar): 44-58

Posada D, Crandall KA (1998) MODELTEST: testing the model of DNA substitution. Bioinformatics 14: 817-818

Schmitz A, Mausfeld P, Embert D (2004) Molecular studies on the genus Eumeces Wiegmann, 1834: phylogenetic relationships and taxonomic implications. Hamadryad 28: 73-89

Shimizu Y, Ueshima R (2000) Historical biogeography and interspecific mtDNA introgression in Euhadra peliomphala (the Japanese land snail). Heredity 85: 84-96

Smith HM (2005) Plestiodon: a replacement name for most members of the genus Eumeces in North America. J Kansas Herpetol 14: $15-16$

Stejneger L (1907) Herpetology of Japan and adjacent territory. Bull US Natl Mus 58: $1-x x+1-577$

Su ZH, Tominaga O, Okamoto M, Osawa S (1998) Origin and diversification of hindwingless Damaster ground beetles within the Japanese islands ans deduced from mitochondrial ND5 Gene Sequences (Coleoptera, Carabidae). Mol Biol Evol 15: 10261039

Sugimura A (1972) Plate boundaries in and near Japan. Kagaku 42(4): 192-202 (in Japanese)

Takahashi M, Saito K (1997) Miocene intra-arc bending at an arcarc collision zone, central Japan. Isl Arc 6: 168-182

Takahata N, Slatkin M (1984) Mitochondrial gene flow. Proc Natl Acad Sci USA 81: 1764-1767

Taylor E (1936) [1935] A taxonomic study of the cosmopolitan sincoid lizards of the genus Eumeces with an account of the distri- 
bution and relationships of its species. Kansas Univ Sci Bull 23: $1-643$

Thompson JD, Gibson TJ, Plewniak F, Jeanmougin F, Higgins DG (1997) The ClustalX windows interface: flexible strategies for multiple sequence alignment aided by quality analysis tools. Nucleic Acids Res 24: 4876-4882

Toda M, Hikida T, Ota H (2001a) Discovery of sympatric cryptic species within Gekko hokouensis (Gekkonidae: Squamata) from the Okinawa Islands, Japan, by use of allozyme data. Zool Scr 30: $1-11$

Toda M, Okada S, Ota H, Hikida T (2001b) Biochemical assessment of evolution and taxonomy of the morphologically poorly diverged geckos, Gekko yakuensis and G. hokouensis (Reptilia: Squamata) in Japan, with special reference to their occasional hybridization. Biol J Linn Soc 73: 153-165
Tominaga A, Matsui M, Nishikawa K, Sato S (2003) Occurrence of two types of Hynobius naevius in Northern Kyushu, Japan (Amphibia: Urodela). Zool Sci 20: 1467-1476

Wada H, Makabe KW, Nakauchi M, Satoh N (1992) Phylogenetic relationships between solitary and colonial ascidians, as inferred from the sequence of the central region of their respective 18S rDNA. Biol Bull 183: 448-455

Watanabe $Y$, Chiba S (2001) High within-population mitochondrial DNA variation due to microvicariance and population mixing in the land snail Euhadra quaesti (Pulmonata: Bradybaenidae). Mol Ecol 10: 2635-2645

(Received September 12, 2005 / Accepted February 10, 2006)

Appendix 1. List of locality names and catalogue numbers (KUZ) of the specimens examined in this study. Numbers for the localities correspond to those in Fig. 1.

\section{Plestiodon latiscutatus and $P$. japonicus}

1, Sapporo, Hokkaido, KUZ R45154; 2, Mt. Hakkoda, Aomori, Aomori Pref., KUZ R30677; 3, Mt. Tenso, Okutama, Tokyo Metro., KUZ R58303; 4, Miyakejima Is., the Izu Islands, Tokyo Metro. KUZ R36495; 5, Azumi, Nagano Pref., KUZ R39024; 6, Kasahara, Gifu Pref., KUZ R45929; 7, Tsuruga, Fukui Pref., KUZ R51175; 8, Otsu, Shiga Pref., KUZ R58302; 9, Yamasaki, Hyogo Pref., KUZ R51930; 10, Saijo, Ehime Pref., KUZ R50633; 11, Kagoshima, Kagoshima Pref., KUZ R46921; 12, Yamato, Yamanashi Pref., KUZ R51139-51144; 13, Narusawa, Yamanashi Pref., KUZ R51137, 51138, 51162; 14, Shimobe, Yamanashi Pref., KUZ R51130-51133, 51135, 51136; 15, Samukawa, Kanagawa Pref., one uncataloged specimen; 16, Oiso, Kanagawa Pref., one uncataloged specimen; 17, Kouzu, Odawara, Kanagawa Pref., four uncataloged specimens; 18, Matsuda, Kanagawa Pref., KUZ R60271-60278; 19, Shiroyama, Odawara, Kanagawa Pref., four uncataloged specimens; 20, Tsukahara, Minami-ashigara, Kanagawa Pref., KUZ R60246-60255; 21, Nuda, Minami-ashigara, Kanagawa Pref., KUZ R60260-60266; 22, Yamakita, Kanagawa Pref., KUZ R60267-60270; 23, Yamanakako, Yamanashi Pref., KUZ R58313, 58314; 24, Subashiri, Oyama, Shizuoka Pref., KUZ R58315-58319, 59595, 59596, 60100-60103; 25, Tamaho, Gotenba, Shizuoka Pref., KUZ R60104-60114, one uncataloged specimen; 26, Higashitanaka, Gotenba, Shizuoka Pref., KUZ R60115-60129; 27, Sengokuhara, Hakone, Kanagawa Pref., KUZ R60130; 28, Hakone, Hakone, Kanagawa Pref., one uncataloged specimen; 29, Tsukaharashinden, Mishima, Shizuoka Pref., one uncataloged specimen; 30, Taisha, Mishima, Shizuoka Pref., one uncataloged specimen; 31, Yamamiya, Fujinomiya, Shizuoka Pref., KUZ R60137-60144; 32, Utsuno, Fujinomiya, Shizuoka Pref., KUZ R60407; 33, Kamijo, Fujinomiya, Shizuoka Pref., KUZ R51160, 60313, 60314, 60394-60402, one uncataloged specimen; 34, Aokidaira, Fujinomiya, Shizuoka Pref., KUZ R60403-60405; 35, Yagisawa, Nambu, Yamanashi Pref., KUZ R60311, 60312, 60315, 60316; 36, Fukushi, Nambu, Yamanashi Pref., KUZ R60310, 60411, 60412, one uncataloged specimen; 37, Iwabuchi, Fujikawa, Shizuoka Pref., KUZ R60317-60333; 38, Atami, Shizuoka Pref., KUZ R36328, 36340; 39, Shuzenji, Shizuoka Pref., KUZ R58274; 40, Amagiyugashima, Shizuoka Pref., KUZ R36363,36373; 41, Itou, Shizuoka Pref., KUZ R36400, 36403; 42, Inatori, Higashiizu, Shizuoka Pref., KUZ R36285, 36286; 43, Shimoda, Shizuoka Pref., KUZ R36318, 36323,36334-36336, one uncataloged specimen; 44, Hatsushima Is., Atami, Shizuoka Pref., KUZ R36048, 36140, 36141, one uncataloged specimen; 45, Oshima Is., the Izu Islands, Tokyo Metro., KUZ R51161; 46, Niijima Is., the Izu Islands, Tokyo Metro., one uncataloged specimen.

\section{P. barbouri}

Kakeroma Is., Amami Group, Kagoshima Pref., KUZ R35982. 